\title{
The Archaean gneiss complex of northern Labrador A review of current results, ideas and problems
}

\author{
DAVID BRIDGWATER and LASSE SCHIØTTE
}

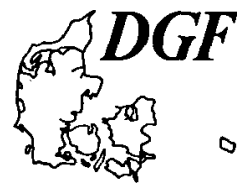

\begin{abstract}
Bridgwater, D. \& Schiøtte, L.: The Archaean gneiss complex of northern Labrador. A review of current results, ideas and problems. Bull. geol. Soc. Denmark, vol. 39, pp. 153-166. Copenhagen, December 20th, 1991. https://doi.org/10.37570/bgsd-1991-39-06

The early Archaean rocks in northern Labrador can be subdivided into the ca. $3.78 \mathrm{Ga}$ Nulliak supracrustal association, the migmatitic Uivak I gneisses, the dominant phase of which was emplaced at ca. $3.73 \mathrm{Ga}$, and the Uivak II augen gneiss. Inherited low- $U$ rounded inclusions within igneous zircons in the Uivak I gneisses have ages between 3.73 and $3.86 \mathrm{Ga}$ and are more likely to have been derived from a pre-existing high-grade metamorphic gneiss complex than from the Nulliak association. In the early Archaean there were probably several rapid cycles of sedimentary deposition and volcanism followed by emplacement of major plutons.

Mid Archaean gneisses are more abundant in northern Labrador than previously realised. The late Archaean metamorphic history of these gneisses is different from the history of the early Archaean gneisses. Whereas an important part of the mid Archaean suite was emplaced in granulite facies and retrogressed at the time of granitoid veining at ca. $2.99 \mathrm{Ga}$, the major part of the early Archaean rocks were reworked under granulite facies conditions in a sequence of closely spaced events between 2.7 and $2.8 \mathrm{Ga}$. The two groups of gneisses had different metamorphic histories until ca. $2.7 \mathrm{Ga}$, but late and post-tectonic granites of $2.5-2.7 \mathrm{Ga}$ age cut across both. It is suggested that the terrane model in southern West Greenland can be extended to Labrador and that tectonic intercalation of early and mid Archaean gneisses took place around $2.7 \mathrm{Ga}$. Correlation between the Maggo gneisses around Hopedale, mid Archaean gneisses in northernmost Labrador and gneisses from the Akia terrane in West Greenland is suggested. Like the Malene supracrustals in West Greenland the Upernavik supracrustals in Labrador are composite associations, the youngest of which are thought to have been deposited around $2.7 \mathrm{Ga}$.
\end{abstract}

D. Bridgwater \& L. Schiøtte, Geological Museum, University of Copenhagen, Østervoldgade 5_7, DK-1350 København K, Denmark, August 8th, 1990.

\section{Introduction: development of ideas}

Compilations of the geology of the Canadian shield since the 1960's (for example Stockwell 1965) have shown that the Archaean of northern Labrador outcrops in two main areas, a northern block from north of Nachvak Fiord to the southern part of the Okak area, here called the Saglek block, and a southern block, the Hopedale block, centered around the village of Hopedale. The two Archaean blocks are truncated to the west and south by early Proterozoic mobile belts and are separated by the mid Proterozoic Nain igneous suite (Fig. 1). Together the two Archaean blocks form the westernmost extent of the North Atlantic craton (Bridgwater et al. 1973).

A more detailed framework of the geology of northern Labrador and the adjacent area of Quebec was established when the Geological Survey of Canada (GSC) began systematic mapping in the period 1968-1970 (see Taylor 1979) and at this time cooperative research was begun between Canadian and Danish research groups to establish correlations across the Davis Strait. This cooperation has continued to the present day and has been widened to include groups from the Newfoundland Department of Mines and the universities of Copenhagen, Århus and Memorial, St. John's, Newfoundland.

In 1969 one of us (D.B., then at the Geological Survey of Greenland) together with B.F. Windley joined the GSC field party in Labrador and spent two weeks in the Saglek Fiord area, firstly examining the contact relations between outliers of the Proterozoic Ramah Group sediments and the underlying Archaean basement and then working on the basement gneisses as far east as the granulite facies - amphibolite facies transition between Shuldham Island and Big Island (Figs 1, 2). This transition is now known to be a major post-Archaean fault zone, the Handy Fault (Bridgwater et al. 1975). In a report submitted to the Geolog- 


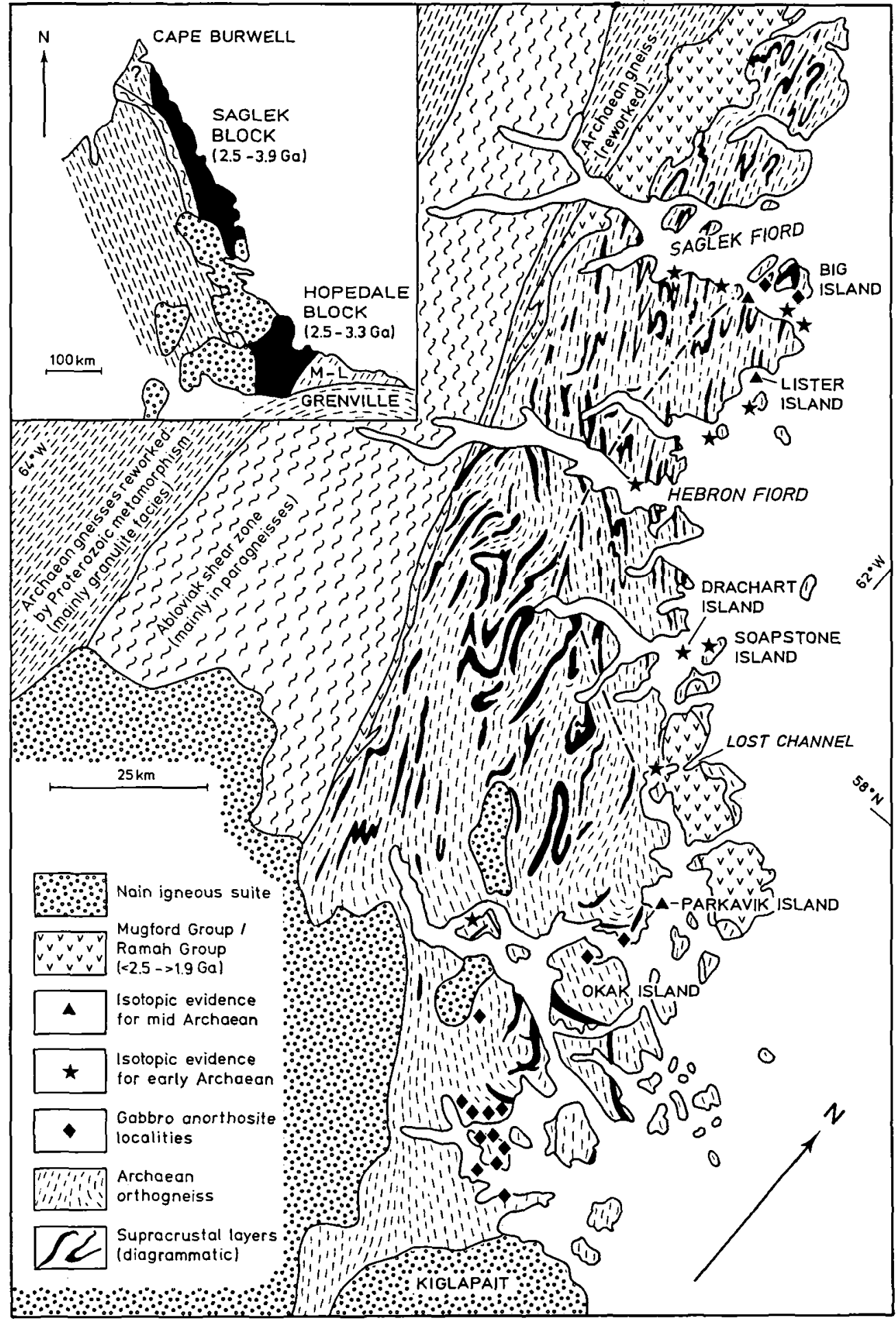

Fig. 1. Simplified map of thı Saglek block in northern Labrador, with inset map showing the location of the Saglek and Hopedale blocks separated by the Nain igneous suite. 
Table 1. Sequence of geological events in northern Labrador.

\begin{tabular}{|c|c|c|c|}
\hline $\begin{array}{l}\text { Approximate } \\
\text { age (Ma) }\end{array}$ & SAGLEK BLOCK & HOPEDALE BLOCK & $\begin{array}{l}\text { Approximate } \\
\text { age (Ma) }\end{array}$ \\
\hline $3730-3860$ & $\begin{array}{l}\text { Age range of rounded inclusions within } \\
\text { igneous zircons in Uivak I gneiss. } \\
\text { Deposition of Nulliak supracrustals (acid } \\
\text { volcanism) dated at } 3780 \mathrm{Ma} \text {. }\end{array}$ & & \\
\hline 3730 & Emplacement of tonalitic Uivak I gneiss. & & \\
\hline \multirow[t]{5}{*}{3620} & $\begin{array}{l}\text { Uivak I gneiss veined by leucocratic grani- } \\
\text { toids. }\end{array}$ & & \\
\hline & Emplacement of Uivak II augen gneiss. & & \\
\hline & Deposition of early "Upernaviks"? & & \\
\hline & Intrusion of porphyritic Saglek dykes. & & \\
\hline & Deposition of some "Upernaviks"? & Deposition of the Hunt River belt? & \\
\hline \multirow[t]{4}{*}{3240} & $\begin{array}{l}\text { Emplacement of intermediate to mafic } \\
\text { gneisses, partly in granulite facies. }\end{array}$ & $\begin{array}{l}\text { Age of } U \text { poor detrital zircons in Weeke's } \\
\text { metasediment. Derived from early phase of } \\
\text { Maggo gneiss emplaced in granulite facies? }\end{array}$ & 3260 \\
\hline & Deposition of late "Upernaviks"? & Deposition of Weeke's metasediment? & \\
\hline & & Main phase of Maggo gneiss. & 3100 \\
\hline & $\begin{array}{l}\text { Intrusion of basic dykes, previously correlated } \\
\text { with the Saglek dykes. }\end{array}$ & Intrusion of Hopedale dykes. & \\
\hline \multirow[t]{2}{*}{2990} & $\begin{array}{l}\text { Emplacement of leucocratic granitoids into } \\
3240 \text { Ma gneisses. }\end{array}$ & $\begin{array}{l}\text { Hopedalian deformation, migmatisation and } \\
\text { metamorphism in upper amphibolite facies. }\end{array}$ & \\
\hline & $\begin{array}{l}\text { Tectonic intercalation of some orthogneisses } \\
\text { and supracrustals. }\end{array}$ & $\begin{array}{l}\text { Emplacement of the Kanairiktok granitoids } \\
\text { followed by Fiordian } \\
\text { deformation and metamorphism in lower } \\
\text { amphibolite facies. }\end{array}$ & 2840 \\
\hline \multirow[t]{2}{*}{$2700-2800$} & $\begin{array}{l}\text { High grade metamorphism reaching granulite } \\
\text { grade in a major part of the area, partial } \\
\text { melting and migmatisation by leucocratic } \\
\text { granitoid sheets with mixed isotopic signature. }\end{array}$ & & \\
\hline & $\begin{array}{l}\text { Deposition of very late "Upernaviks" fol- } \\
\text { lowed by further tectonic intercalations? }\end{array}$ & & \\
\hline $2685^{*}$ & $\begin{array}{l}\text { Discrete late-tectonic sheets cutting both early } \\
\text { and mid Archaean gneisses. }\end{array}$ & & \\
\hline \multirow[t]{2}{*}{2560} & Intrusion of post-tectonic granites. & & \\
\hline & Intrusion of basic dykes. & Intrusion of basic dykes. & \\
\hline 1800 & $\begin{array}{l}\text { Early Proterozoic thermal event. Deformation } \\
\text { along Proterozoic dykes. }\end{array}$ & $\begin{array}{l}\text { Makkovikian deformation and metamor- } \\
\text { phism. }\end{array}$ & \\
\hline
\end{tabular}

*The procedure for zircon U-Pb dating of this rock was not very sophisticated (Schiøtte 1988), and future work may result in second order changes of the age.

Italics denote events within the Saglek block that suggest correlation with the Hopedale block (see text for further explanation),

ical Survey of Canada (which had too many unproven ideas to be accepted for publication) D.B. and B.F.W. noted the presence of metamorphosed and highly deformed basic dykes (later known as the Saglek dykes, Bridgwater et al. 1975), the intrusion of which predated the regional granulite facies metamorphism seen in the west of the area. Using similar arguments to those put forward in West Greenland by McGregor (1968), it was suggested that the geological development of the Saglek area began well before $3 \mathrm{Ga}$.

The isotopic demonstration that the earliest units in West Greenland were among the oldest 
continental crustal rocks then known (Black et al. 1971) encouraged the search for old rocks in northern Labrador. The first isotopic evidence that early Archaean rocks are indeed around in this part of the North Atlantic craton was provided by Hurst (1973, multigrain U-Pb zircon study), Barton (1975, whole rock Rb-Sr) and Hurst et al. (1975, whole rock Rb-Sr). The chronological significance of cross-cutting Saglek dykes was only appreciated by the latter group, but later field investigations have shown that the gneisses at all three localities are intruded by numerous Saglek dykes (field observations by DB and LS 1987; Bridgwater et al. 1990). The locality sampled for Rb-Sr work by Barton (7.5 $\mathrm{km} \mathrm{SW}$ of Hebron village) is so far unique on the Labrador coast in that intrusive relationships between different phases of early Archaean granitoid rocks are as well preserved as in the gneisses of the Isukasia area in West Greenland (Nutman \& Bridgwater 1984).

Regional mapping of the Archaean and Proterozoic rocks north of Saglek Fiord was carried out in 1971-1972 by a GSC party lead by W.C. Morgan (Morgan 1979, 1981). At this reconnaissance level of mapping it was not possible to make stratigraphic subdivisions of the dominant Archaean basement granulite facies quartzo-feldspathic gneisses. The excellent map that was published (Morgan 1979), however, shows the same type of outcrop patterns as those familiar from Greenland, where supracrustal rocks $(10 \%$ of outcrop) occur as concordant layers and constitute a pattern of domes that are elongated into the dominant N-S structural grain.

From early work in the Saglek block it was clear that late Archaean crustal reworking of the early Archaean gneiss complex was more important in northern Labrador than in West Greenland (Baadsgaard et al. 1979; Collerson et al. 1981, 1982, 1989; Hurst et al. 1975). Partial melting of early Archaean gneiss and more complicated fluid controlled element transfers between early and late Archaean rock suites have been suggested as integral parts of this reworking process (Schiøtte et al. 1986; Schiøtte \& Bridgwater 1990). The interpretation of whole rock isotopic age dating systems was thereby complicated. On the other hand, equivalents to the type Nûk gneisses in West Greenland appeared to be scarce or absent in the Saglek block.
The ages quoted for the mid to late Archaean events in Labrador $(2.5-3.1 \mathrm{Ga})$ were mostly imprecise and the establishing of a detailed event chronology had to await more sophisticated ion microprobe within-grain zircon $\mathrm{U}-\mathrm{Pb}$ age studies. Furthermore some of the early whole rock studies were made on what are now thought to be composite rock collections.

\section{Chronology}

A comparative chronology for the northern (Saglek) block and the southern (Hopedale) block is presented in Table 1. Apart from the approximate dates of early Proterozoic events, the ages are based on zircon U-Pb studies (conventional multigrain and single zircon studies as well as ion microprobe within-grain zircon studies performed on the SHRIMP at Australian National University). Thereby they are more precise and accurate than whole rock ages obtained during early work in Labrador; in some cases minor adjustments of ages quoted in the earlier papers have been necessary.

\section{Saglek block}

Detailed zircon $\mathrm{U}-\mathrm{Pb}$ age studies have been concentrated in the Saglek-Hebron area (Schiøtte $e t$ al. $1989 \mathrm{a}, \mathrm{b})$, but preliminary data for the Okak area (Fig. 1) are also available now (Schiøtte $e t$ al. 1990a). A regional sample collection is at present being studied in an attempt to carry the main subdivisions of the chronology from Saglek Fiord northwards.

The early Archaean: Three main lithological suites have been recognised as early Archaean: the Nulliak supracrustal assemblage, the Uivak I tonalitic to granodioritic gneisses, and the Uivak II augen gneisses. The Nulliak assemblage consists of chemical sediments and subordinate clastic sediments, (redeposited) acid volcanic sequences, basic volcanic rocks, layered basic rocks and ultramafic material derived from intrusions into the sedimentary - volcanic sequence together with ultrabasic rocks of uncertain origin. The assemblage occurs as rafts and inclusions in grey gneisses. A depositional age of $3776 \pm 8 \mathrm{Ma}$ $(2 \sigma)$ is suggested from the age of igneous zircons 
in a redeposited acid volcanic member of the assemblage (Schiøtte et al. 1989b).

The Uivak I gneisses are layered tonalitic to granodioritic gneisses migmatised by the widespread injection of pegmatitic sheets (Bridgwater \& Collerson 1976). They constitute approximately $60 \%$ of the Archaean gneiss complex in the Saglek-Hebron area. The main grey gneiss and the earliest generations of pegmatite sheets (pre-Saglek dyke) have been treated as a single unit since on most outcrops the intruded material occurs as centimetre scale layers which show considerable chemical exchange with the adjacent grey gneiss. U-Pb ages of igneous zircons from samples taken on either side of the Handy fault agree to within error at an emplacement age of $3732 \pm 6$ Ma (2o). This confirms what was long suspected - that the main grey gneiss phase in the strongly reworked granulite facies area correlates with the main grey gneiss phase in the amphibolite facies area around the mouth of Saglek Fiord.

The Uivak II augen gneisses are coarse-grained quartz- monzonites and porphyritic Fe-rich granodiorites together with subordinate metagabbroic units. They form a distinctive but volumetrically small component of the gneiss complex and contain inclusions of layered Uivak I gneisses. Preliminary ion microprobe $\mathrm{U}-\mathrm{Pb}$ zircon data by Collerson (1983) are consistent with an emplacement age between 3.3 and $3.6 \mathrm{Ga}$.

The Upernavik supracrustal rocks and their possible provenance: In the original field chronology the term Upernavik supracrustal rocks was introduced for suites of metasediments, basic volcanic rocks, associated basic intrusions and ultramafic pods which outcrop as concordant layers intercalated with the adjacent Uivak gneisses. Individual layers can be traced for tens of kilometres along strike and are up to a kilometre wide. Contacts are either tectonic or have been so severely modified by later injection of granitic material that the original relations with the gneisses are obliterated. In some of the main outcrops from which they were first described (St. John's Harbour - Big Island in Saglek Fiord) the Upernavik supracrustal rocks are not seen to be intruded by Saglek dykes. In areas affected by late Archaean granulite facies metamorphism, for example west of the Handy Fault, the intercalation of Upernavik supracrustals with the gneisses is seen to predate this metamorphism.
Thus the chronological position of the Upernavik supracrustals was thought to be similar to the position of the Malene supracrustals in West Greenland (McGregor 1973; Bridgwater et al. 1974).

Recently the Malene supracrustals in West Greenland have been shown to be a composite assemblage with some units of clastic sediments deposited late in the event chronology - between ca. 2.9 and $2.65 \mathrm{Ga}$ (Schiøtte et al. 1988). Multigrain Lu-Hf zircon data from Upernavik metasediments (Stevenson \& Patchett 1990) now suggest that the same may be true for the Upernavik supracrustals in northern Labrador: detrital zircons from Upernavik metasediments on either side of the Handy Fault have yielded distinctly different Lu-Hf CHUR model ages (ca. 3.4 Ga for samples from the granulite facies area as opposed to ca. 3.1 Ga for samples collected on the east side of St. John's Harbour in the amphibolite facies area, Figs 1, 2). Although metamorphic recrystallisation and the inherent limitations in the use of the CHUR model may have biased these ages relative to the age of deposition, there is no easy way that such a bias could account for the age difference between east and west.

Whole rock Sm-Nd isochron ages obtained on basic Upernavik supracrustals are equivocal, but data obtained on metasediments are consistent with the pattern suggested by the Lu-Hf zircon ages (Schiøtte et al. 1990b). Moreover Bridgwater et al. (1990) report that some granulite facies supracrustal units with "Upernavik-like" lithologies have been seen to be cut by Saglek dykes, an observation that further supports our contention that the Upernavik supracrustals include the remnants of sequences of several ages.

A possible candidate for the source terrane to the younger Upernavik metasediments is represented by the $3.24 \mathrm{Ga}$ Lister gneiss (Schiøtte et al. 1989a). In previous studies this mid Archaean amphibolite facies gneiss has been regarded as a volumetrically subordinate component of the Archaean gneiss complex, but it is probable that equivalents to the Lister gneiss could be present among some of the composite suites of rocks that were used for early whole rock isotopic studies. After reexamination of field data and isotopic signatures for individual samples belonging to the so-called undifferentiated gneisses (Hurst et al. 1975) and Saglek sheets (Collerson et al. 1981) we 


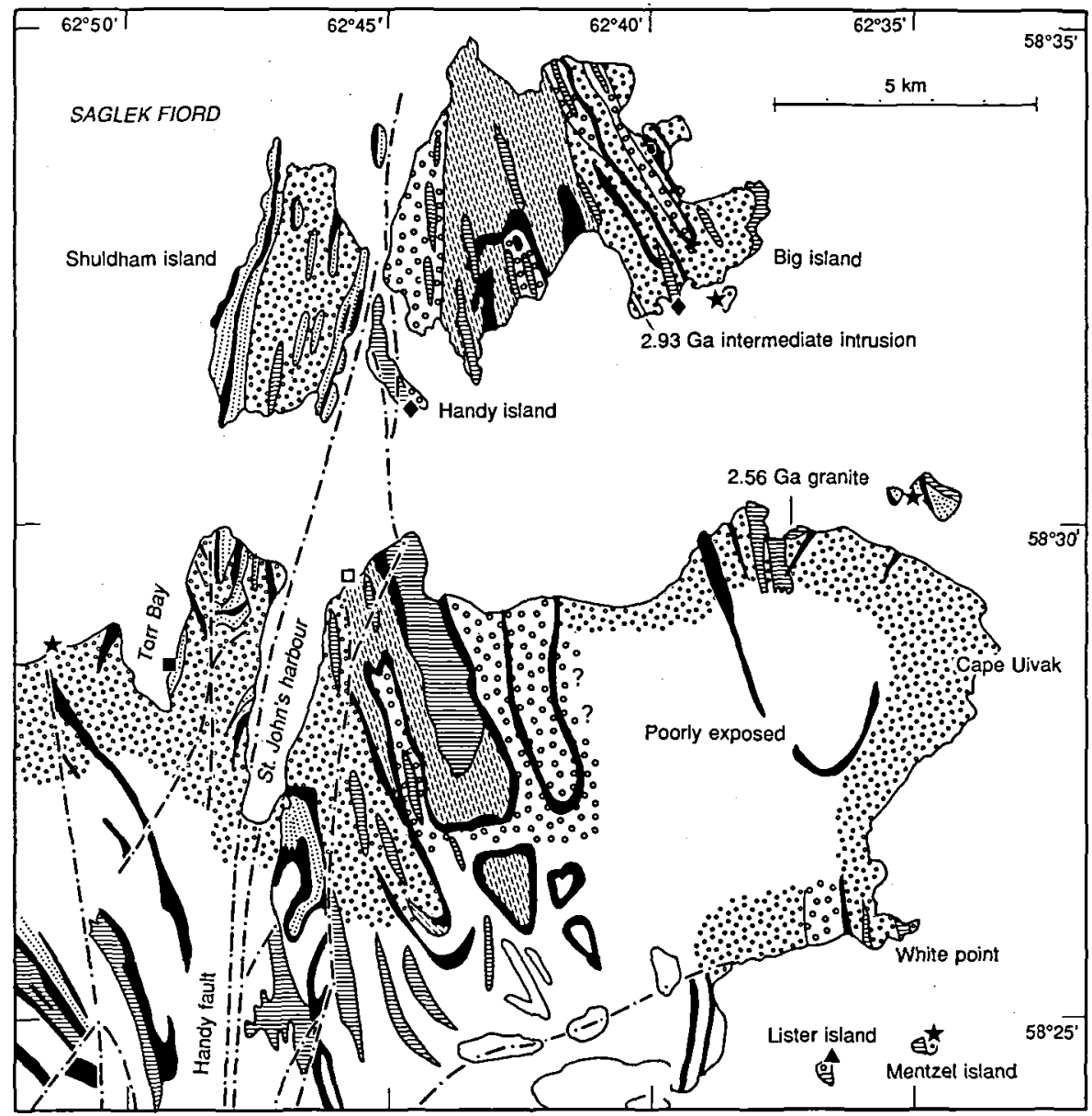

$\because \because \because \because$ Uivak gneiss (affected by $2.7-2.77$ Ga granulite facies metamorphism $\therefore \because \therefore:$ west of the Handy fault)

$\because 00 \%$ Lister gneiss and units without Saglek dyke remnants

Suggested late Archaean supracrustals (sediments plus basic/ultrabasic
units affected by late Archaean amphibolite facies metamorphism)

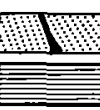

Early to mid Archaean and unclassified supracrustal units

Late Archaean granitoid sheets (diagramatic)

* $\quad \mathrm{U} / \mathrm{Pb}$ zircon evidence for early Archaean gneiss

- $\quad \mathrm{U} / \mathrm{Pb}$ zircon evidence for mid Archaean gneiss

- Lu/Hf evidence for mid Archaean zircon component in sediments

- Lu/Hf evidence for sediments with dominantly early Archaean zircons.

- Gabbro anorthosite fragments in mid to late Archaean gneisses

Boundaries between parts of the area dominated by mid to late Archaean and early Archaean gneisses correspond to divisions made in Bridgwater et al. (1975, fig. 2). Distinction largely arbitrary inland.

Fig. 2. Detail map of the Saglek Fiord area with the possible distribution of mid Archaean gneisses. 
suggest that gneisses approximately contemporaneous with the Lister gneisses crop out in a relatively large area within the amphibolite facies terrane around the mouth of Saglek Fiord (Fig. 2). Abundant mafic granulite facies orthogneisses from the Okak area have been shown to be of Lister gneiss age (Schiøtte et al. 1990a). The mid Archaean amphibolite facies gneisses around Saglek Fiord are devoid of cross-cutting dykes, but the granulite facies gneisses in the Okak area are occasionally cut by basic dykes that were previously correlated with the Saglek dykes. As opposed to the type Saglek dykes, these dykes are non-porphyritic.

The late Archaean chemical reworking: Only a minor part of the exposed early Archaean rocks has escaped late Archaean granulite facies metamorphism. The amphibolite facies gneisses east of the Handy Fault (Figs 1,2) only extend as far south as Lister Island. South of this island the gneisses are transitional to granulite facies, but even farther south (around Soapstone Island) there is another small area where the gneisses at the present level of exposion escaped granulite facies metamorphism. As was found in the Saglek Fiord area, this outcrop pattern is controlled by post-Archaean faults.

Zircon U-Pb studies have constrained the age of the late Archaean chemical reworking that affected the major part of the early Archaean gneisses to the period between 2.8 and $2.7 \mathrm{Ga}$ (Schiøtte 1988; Schiøtte et al. 1989a, 1990a). A sequence of events comprising several generations of recrystallisation, partial melting and emplacement of discordant leucocratic granitoids has been recorded in this time interval. The isotopic composition of $\mathrm{Nd}$ in the leucocratic granitoid sheets is intermediate between the Nd composition of the Uivak gneisses and a juvenile (CHUR like) source at the time of their emplacement. In some places element transfer took place between the granitoids and the Uivak gneisses leading to an anomalously juvenile isotopic signature within the latter. Brief periods of retrogression separated periods of recrystallisation in granulite facies (Schiøtte \& Bridgwater 1990).

While the late Archaean reworking pattern can be recognised in early Archaean gneisses southwards into the Okak area, it is striking that a quite different metamorphic history is recorded in zircons from mafic gneisses with emplacement ages similar to the Lister gneiss farther north. Thus on Parkavik Island the gneisses have crystallised in granulite facies and have subsequently been retrogressed to a varying extent long before the onset of late Archaean granulite facies metamorphism in the early Archaean gneisses. The retrogression is interpreted as intimately associated with the emplacement of leucocratic granitoids at ca. $2.99 \mathrm{Ga}$ (Schiøtte et al. 1990a), and there is no record of events between 2.8 and 2.7 $\mathrm{Ga}$. Low $\mathrm{U}$ contents (ca. $30 \mathrm{ppm}$ ) in the igneous zircons in the main gneiss suggest that part of the mid Archaean gneiss suite was emplaced as $\mathrm{U}$ depleted granulites at ca. $3.24 \mathrm{Ga}$.

Monazite $\mathrm{U}-\mathrm{Pb}$ ages between 2.51 and $2.57 \mathrm{Ga}$ are recorded from both the early and the mid Archaean gneisses in the Okak area (Schiøtte et al. 1990a), and the mid Archaean gneisses are cut by pink-grey granite sheets that resemble granite sheets dated at ca. $2.69 \mathrm{Ga}$ in the Saglek-Hebron area (Schiøtte 1988). From about this time onwards the early and mid Archaean gneisses followed the same metamorphic path. The boundary between these contrasting gneiss generations has not been mapped in detail, but it approximately follows the coast line between Okak and Lost Channel (Fig. 1).

The whole of the gneiss complex was affected by several phases of strong deformation concentrated along ca. $140^{\circ}$ to N-S trending zones. The majority of these late Archaean structures are approximately vertical, but locally sub-horizontal structures suggest thrust movements under amphibolite facies conditions towards the end of the Archaean. The youngest post-tectonic granite from the Saglek block has given a U-Pb zircon age of ca. $2.56 \mathrm{Ga}$ (highest $207 \mathrm{~Pb} / 206 \mathrm{~Pb}$ age of individual multigrain fraction analysed by Baadsgaard et al. 1979). There is a high abundance of such late Archaean granites which postdate development of the main structures close to the inferred boundary between early and mid Archaean gneisses. The Okak granite which crops out on northern Okak island and on the mainland along the coast between Okak and Lost Channel is a prominent example. The geochemistry of these granites suggests that they were formed from melted sialic crust.

Anorthosites: Coarse-grained gabbro anorthosite fragments derived from layered intrusions are abundant in the gneisses from the Okak area. 
Their age is not well constrained, but they are petrologically and chemically similar to the late Archaean layered anorthosites of West Greenland (Myers 1973; Weiner 1981) and fragments seen in parts of the Hopedale area (Ermanovics et al. 1982). North of Okak they have been identified on the southern side of Handy Island and Big Island in Saglek Fiord where they are found as highly broken up inclusions in late Archaean granitic migmatite zones. Major bodies are reported close to the Archaean/Proterozoic boundary from the Nachvak Fiord area and farther north (Taylor 1979; Wardle 1983) but their stratigraphic position is unknown.

\section{Hopedale block}

The Maggo gneisses of the Hopedale area are a composite suite of migmatitic orthogneisses. Loveridge et al. (1987) obtained a multigrain $\mathrm{U}-\mathrm{Pb}$ age of $3105+6 /-9 \mathrm{Ma}$ for zircons from one of the important gneiss phases west of Hopedale village. This was interpreted as an emplacement age. Indications of earlier components were seen in this study, and Schiøtte et al. (1989b) dated low-U zircons from a metasediment belonging to the Weeke's amphibolite supracrustal association (Table 1) at $3258 \pm 24 \mathrm{Ma} \mathrm{(2 \sigma )}$. Textures of these zircons suggest that they are detrital grains of igneous origin. Thus they provide indirect evidence for the existence of an early ca. $3.26 \mathrm{Ga}$ phase of Maggo gneiss. Whole rock Rb-Sr ages in the range $3.2-3.3 \mathrm{Ga}$ have been obtained for early phases of the Maggo gneisses (Grant et al. 1983; Finn 1989), but the ages are too imprecise to ascertain whether these gneisses could be the source from which the ca. $3.26 \mathrm{Ga}$ zircons were derived.

The Maggo gneisses were intruded by porphyritic tholeiite dykes (comparable in character if not necessarily in age with the Saglek dykes). They were affected by two phases of late Archaean deformation and granitoid emplacement: the Hopedalian with a structural grain trending NW-SE, and the Fiordian with a structural grain trending approximately NE-SW (Ermanovics et al. 1982). The age of the Hopedalian event is poorly constrained, but Maggo gneisses with a Hopedalian imprint gave ca. 3.0 Ga whole rock $\mathrm{Rb}-\mathrm{Sr}$ ages in the study by Grant et al. (1983). Finn (1989) interpreted ca. 3.1 Ga Rb-Sr ages as
Hopedalian, but in our interpretation they could just as well be emplacement ages. The $2.84 \mathrm{Ga}$ Kanairiktok plutonic suite and associated migmatites (Loveridge et al. 1987; Schiøtte et al. 1989b) pre- to syn-date the Fiordian event. In the western part of the Hopedale block there are indications of a pre-Hopedalian granulite facies event (Ermanovics et al. 1982). If the earliest phases of the Maggo gneisses were emplaced in granulite facies, this could account for the low- $U$ state of the ca. $3.26 \mathrm{Ga}$ detrital zircons in the metasediment from the Weeke's amphibolite association.

\section{Labrador in the context of current ideas of crustal evolution}

The nature of early Archaean crustal formation

The isotopic evidence cited above suggest that early Archaean Uivak gneisses are abundant in the major part of the Saglek block. Some of the younger among $>3.73 \mathrm{Ga}$ rounded inclusions within the igneous zircons in the Uivak gneisses (Table 1) correlate with the age of acid volcanic rocks within the Nulliak assemblage (Schiøtte $e t$ al. 1989 a,b). However, the low $U$ content and massive state of this inherited zircon component suggest derivation from a high grade metamorphic gneiss complex. The oldest inclusion dated has an age of $3863 \pm 12 \mathrm{Ma} \mathrm{(2 \sigma )}$ (Schiøtte et al. 1989a) which does not correspond to the age of any known rock complex. It is suggested that the Uivak grey gneisses contain an appreciable component of older crustal material, something that should be considered when whole rock isotopic data for juvenile tonalitic gneisses are interpreted in terms of "mantle reservoirs". The succession of events in the early Archaean was probably not a single cycle of ocean floor-like volcanism and sedimentation followed by tonalite-granodioritegranite generation. It is more likely to have involved a series of interrelated plutonic/volcanic events.

Our preferred model for the formation of early Archaean continental crust is that proto-oceanic crust was subducted in an environment similar to present day subduction zones but that individual plates were small and less separated into conti- 
nental and oceanic regimes in comparison to those of the present day.

\section{Late Archaean terrane assemblage?}

Recently it has been demonstrated that the Archaean gneiss complex in southern West Greenland consists of a mosaic of terranes with different early histories that were tectonically assembled between ca. 2.75 and $2.65 \mathrm{Ga}$ (Friend $e t$ al. 1987, 1988; Nutman et al. 1989). A similar pattern has not previously been found in northern Labrador where, among other differences, the areal extent of the early Archaean gneisses is much larger than in West Greenland. However, it is striking that the mid Archaean gneisses in the Saglek block show no sign of having been through the granulite facies reworking event between 2.8 and $2.7 \mathrm{Ga}$, whereas the early Archaean Uivak gneisses show no sign of the 2.99 $\mathrm{Ga}$ event. The two gneiss types also seem to have different dyke chronologies.

If it is assumed that the mid Archaean gneisses were tectonically intercalated with, rather than intrusive into the early Archaean Uivak gneisses, then much of the tectonism that accounts for the present outcrop pattern would be as young as ca. $2.7 \mathrm{Ga}$. Tectonic intercalation at such a late stage would also allow the Upernavik supracrustals from the amphibolite facies area east of St. John's Harbour to be deposited after the main granulite facies reworking event affected the Uivak gneisses. Future isotopic studies of detrital zircons from this supracrustal unit are needed to test this suggestion.

The original character of the contacts between early and mid Archaean gneisses is often obscured by granite veining, and it is possible that the emplacement of the post-tectonic $2.56 \mathrm{Ga}$ granites was controlled by the ca. $2.7 \mathrm{Ga}$ suture. A comprehensive single zircon $\mathrm{U}-\mathrm{Pb}$ age study of the various late Archaean granitoid generations is needed before a detailed model of the tectonic juxtaposition event can be proposed. Currently one of us (L.S.) regards the emplacement of the majority of leucocratic granitoid sheets in the Saglek-Hebron area (Table 1) as an integral part of the $2.8-2.7 \mathrm{Ga}$ reworking event predating the tectonic juxtaposition. On the other hand D.B. suggests that the emplacement of at least some of these sheets could be related to the juxtaposition event. If granitoids were generated from melting of mid Archaean gneisses underlying early Archaean Uivak gneisses, this could account for their anomalously juvenile $\mathrm{Nd}$ isotopic composition.

The fact that inherited zircons of Uivak age have not been reported from the mid Archaean gneisses accords with our suggestion that the latter were juxtaposed on rather than penetrating the early continent. Whole rock Sm-Nd and $\mathrm{Pb}-\mathrm{Pb}$ data for the mid Archaean granulite facies gneisses on Parkavik Island (Fig. 1) suggest that these gneisses are juvenile additions to the continental crust (Schiøtte et al. 1990c). However, it is puzzling that similar data for the type Lister gneiss (Schiøtte 1988, 1989) suggest a source that was already mildly $U$ depleted and LREE enriched relative to the mantle at $3.24 \mathrm{Ga}$. We have previously suggested that trace elements with anomalous isotopic signature could be introduced to gneisses as part of the late Archaean reworking process (Schiøtte et al. 1986; Schiøtte \& Bridgwater 1990), but there remains a problem if the major part of this reworking took place $b e$ fore our proposed juxtaposition.

It is striking that our inferred (ca. $3.26 \mathrm{Ga}$ ) age of the earliest phase of the Maggo gneisses in the Hopedale block is similar or identical to the age of the Lister gneisses and the mafic gneisses on Parkavik Island. Furthermore there are suggestions that in both blocks part of the gneiss suite was emplaced as U-poor granulites. The Hopedalian and Fiordian events that affect the Hopedale block are significantly older than the reworking event recorded in the Uivak gneisses. Future high precision U-Pb zircon studies in the Hopedale block are needed to tell whether the ca. $3 \mathrm{Ga}$ Hopedalian event correlates with the ca. $2.99 \mathrm{Ga}$ event on Parkavik Island. We tentatively suggest that they do, and that the mid Archaean gneisses in the Saglek block are tectonic slivers of a separate terrane represented by the Maggo gneisses in the Hopedale block. To understand the geometry of these slivers it is an important observation that early Archaean rocks are found both on the eastern and the western side of the mid Archaean gneisses in the Saglek Fiord area. The regional distribution of lumps of anorthosite suggests that they are a characteristic of the mid Archaean gneiss terrane.

As a corollary on the model we note that the 


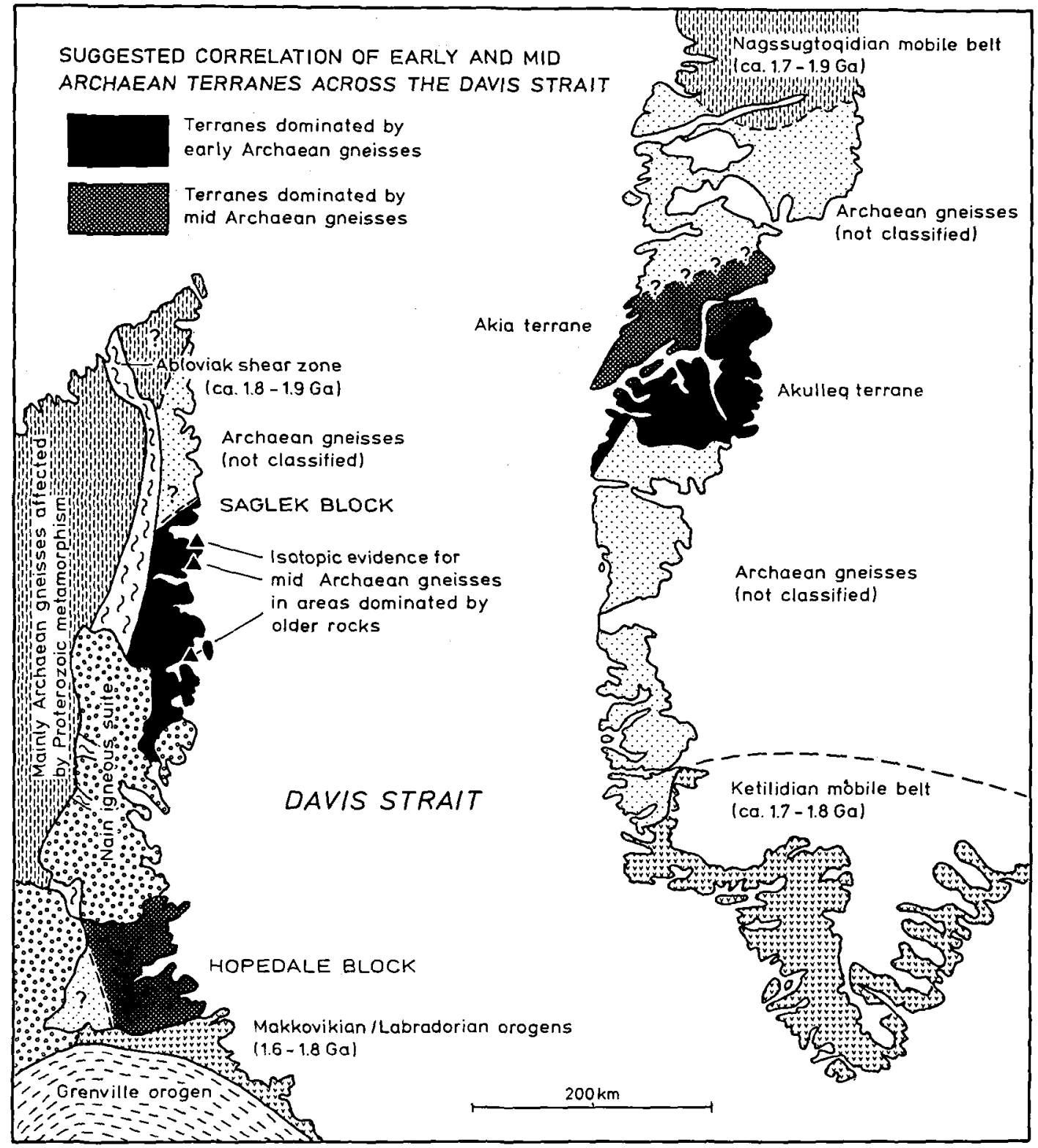

Fig. 3. Map comparing Archaean terranes in northern Labrador and southern West Greenland. The revised nomenclature by McGregor et al. (1991) has been used for the early Archaean terrane of West Greenland. The two land masses are shown in pre-drift position.

porphyritic Hopedale dykes show stronger resemblance to the type Saglek dykes than to the dykes from Parkavik Island. Apparently chronology based on different types of dykes does not work on the scale of the distance between the Okak area and Hopedale, even within the same terrane.

\section{A Greenlandic connection?}

The early Archaean rocks in northern Labrador must in some way be intimately related to the early Archaean rocks in West Greenland. The emplacement age for the main phase of the Uivak gneisses is comparable, if not identical, to the emplacement age of those Amîtsoq gneisses that 
intrude the Isua supracrustals at Isukasia (Baadsgaard et al. 1986). The depositional age of the Nulliak supracrustals is within error consistent with the age of the Akilia association suggested by single zircon U-Pb age studies (Schiøtte \& Compston 1990). The somewhat older age of the Isua supracrustals $(3.81 \mathrm{Ga}$, Compston et al. 1986) and the evidence that gneisses with ages in the range $3.82-3.89 \mathrm{Ga}$ were present in outer Godthåbsfjord, West Greenland (Kinny 1986; Kinny et al. 1988) lends further support to our contention that there were several rapid cycles of sedimentation and volcanism followed by plutonism.

The emplacement ages of the mid Archaean orthogneisses in the Hopedale and Saglek blocks are not directly correlative with any published age from gneisses in West Greenland. However, in terms of emplacement processes and metamorphic history there are similarities between the mid Archaean Labrador gneisses and the Nûk gneisses of the Akia terrane (Nutman et al. 1989) in West Greenland (Fig. 3). Both around Hopedale and in the Akia terrane there is a multitude of orthogneiss phases, and the $3105 \mathrm{Ma}$ age of one of the main phases around Hopedale (Loveridge et al. 1987) is comparable to the earliest age yet obtained for a Nûk gneiss (3065 Ma, Baadsgaard \& McGregor 1981). In both places there are indications that some orthogneisses initially crystallised with granulite facies assemblages and were retrogressed between 2.95 and $3.0 \mathrm{Ga}$, possibly in close association with the generation of anatectic granites (Garde 1989). This retrogression event predates the main reworking events in adjacent terranes (Nutman et al. 1989; Schiøtte et al. 1989 c).

Although no equivalent of the Lister gneiss has yet been identified in West Greenland, there are several possible candidates among the earliest phases of the Nûk gneisses in the Akia terrane. In this context it is interesting that two detrital zircons from a metasediment on the island Simiutâ belonging to the composite group called Malene supracrustals have $207 \mathrm{~Pb} / 206 \mathrm{~Pb}$ ages that agree to within error with the age of the Lister gneiss (ion microprobe (SHRIMP) U-Pb zircon studies by Schiøtte et al. 1988, 1989a). The weighted average for four out of five $207 \mathrm{~Pb} / 206 \mathrm{~Pb}$ measurements on these zircons (analyses 3-2, 3-3, 11-1 and 11-2, table 3, Schiøtte et al. 1988) sug- gests an age of $3227 \pm 8 \mathrm{Ma}(2 \sigma)$. The fifth analysis (3-4) was obtained close to a rim and was slightly younger. At the time of publication these zircons were regarded as early Archaean (Amîtsoq) grains that had suffered high amounts of early $\mathrm{Pb}$ loss. Attention was paid to their relatively high discordance. In the meantime the standardisation procedure for $\mathrm{U} / \mathrm{Pb}$ ratios measured on SHRIMP has been revised, and the grains now appear near concordant. We now suggest that they derive from a Greenlandic equivalent to the Lister gneiss.

The concepts of Upernavik and Malene supracrustals are in need of revision on both sides of the Davis Strait. The young Upernavik supracrustals from the amphibolite facies area east of St. John's Harbour in Labrador (Fig. 2) may well have been deposited in the same period as the Malene supracrustals on Rype $\emptyset$ and Simiutâ in Greenland that were investigated by Schiøtte et al. (1988).

The latest granitoids are common to all terranes in both Labrador and Greenland, and their ages constitute a lower limit for the possible age of tectonic intercalation.

\section{Discussion}

We have suggested that the terrane concept of Friend et al. (1987, 1988) and Nutman et al. (1989) can be extrapolated to Labrador and propose correlation between a terrane of mid Archaean gneisses in Labrador and the Akia terrane in West Greenland. There are also similarities between early Archaean terranes on both sides of the Davis Strait; several rapid cycles of sedimentation and volcanism followed by plutonism are suggested for the early Archaean. Terrane assembly terminated around $2.7 \mathrm{Ga}$ both in West Greenland and northern Labrador.

Until the realisation that a significant part of the North Atlantic craton was formed in the period between 3.24 and $2.98 \mathrm{Ga}$ it has been customary to divide crustal generation in the North Atlantic shield into two main periods at about 3.7 $\pm 0.2 \mathrm{Ga}$ and $2.9 \pm 0.2 \mathrm{Ga}$, separated by a period of little tectonic activity. Each crust building episode was regarded as part of a major cycle of events initiated by volcanism followed by subduction-like processes and ending with crustal 
differentiation, the formation of granitic plutons and high grade metamorphism (the CADS concept, e.g. Moorbath \& Taylor 1986). The idea of a major crustal segment in which there were two main plutonic episodes in the early and late Archaean separated by a period of thermal inactivity of up to $500 \mathrm{Ma}$ is not easy to reconcile with an Archaean global thermal regime in which there was several times as much energy available to drive the processes by which the continental crust could be separated from the mantle.

As mapping has progressed in the North Atlantic craton and in particular as methods of dating individual igneous events have improved, this two stage model has had to be modified. Within individual terranes crustal formation and plutonic activity may well be divided into distinct stages with long periods of inactivity, but on the scale of the craton there is almost a continuum of events from the earliest recorded activity around $3.9 \mathrm{Ga}$ through to the late Archaean.

Acknowledgments - This work summarises several years' field work and isotopic studies. We want to thank the colleagues who supported us in our work on both sides of the Davis Strait. In particular the ideas of Vic McGregor, Allen Nutman and Clark Friend are a major contribution to this work. Financial support was received from Canadian funds, the Danish Natural Science Research Council and the Carlsberg Foundation. Chris Pulvertaft is thanked personally for organising the 1989 Steno symposium of which this forms a part. The paper was refereed by Allen Nutman.

\section{Dansk sammendrag}

De gammel-Archaeiske bjergarter i nordlige Labrador kan underinddeles i de ca. $3.78 \mathrm{Ga}$ gamle Nulliak supracrustaler, de migmatitiske Uivak I gnejser og Uivak II øjegnejserne. Den dominerende tonalitiske fase af Uivak I gnejserne har en emplacerings-alder på ca. $3.73 \mathrm{Ga}$. U-fattige afrundede inclusioner i magmatiske zirkoner i Uivak I gnejserne har aldre på mellem $3.73 \mathrm{og} 3.86 \mathrm{Ga}$ og tolkes bedst som stammende fra et aldre højgradigt metamorft gnejs-komplex. I det tidlige Archaeicum var der sandsynligvis flere cykler med sedimentation og vulkanisme efterfulgt af plutonisk aktivitet.

Midt-Archaeiske gnejser er mere udbredte i nordlige Labrador end hidtil antaget. Disse gnejsers sen-Archaeiske metamorfe historie er forskellig fra Uivak gnejsernes. En vigtig del af de midt-Archaeiske gnejser intruderedes således direkte som U-fattige granuliter og blev delvis retrograderet $i$ forbindelse med emplaceringen af leucocrate granitoider ved ca. $2.99 \mathrm{Ga}$. Størstedelen af de gammel-Archaeiske bjergarter undergik derimod granulit-facies metamorfose mellem $2.8 \mathrm{og} 2.7 \mathrm{Ga}$. Først efter ca. $2.7 \mathrm{Ga}$ konvergerer de to gnejs-gruppers metamorfe historie; således er begge skåret af sen-og post-tektoniske graniter med aldre på mellem 2.5 og $2.7 \mathrm{Ga}$. Vi foreslår, at den model for intercalerede terranes, der for nylig er blevet demonstreret $i$ det sydlige Vestgrønland, også kan anvendes i Labrador. I vores model reprasenterer Maggo gnejserne ved Hope- dale, de midt-Archaeiske gnejser længere nordpå i Labrador og gnejserne i Akia terranet i Vestgrønland et og samme terrane. Ligesom Malene supracrustalerne i Vestgrønland er Upernavik supracrustalerne i Labrador en samle-betegnelse for supracrustalserier med vidt forskellige aldre; de yngste har sandsynligvis sedimentations-aldre på omkring $2.7 \mathrm{Ga}$.

\section{References}

Baadsgaard, H., Collerson, K. D. \& Bridgwater, D. 1979: The Archean gneiss complex of northern Labrador: 1. Preliminary U-Th-Pb geochronology. Can. J. Earth Sci. 16, 951961.

Baadsgaard, H. \& McGregor, V. R. 1981: The U-Th-Pb systematics of zircons from the type Nûk gneisses, Godthåbsfjord, West Greenland. Geochim. Cosmochim. Acta 45, 1099-1109.

Baadsgaard, H., Nutman, A. P. \& Bridgwater, D. 1986: Geochronology and isotopic variation of the early Archaean Amîtsoq gneisses of the Isukasia area, southern West Greenland. Geochim. Cosmochim. Acta 50, 2173-2183.

Barton, Jr., J. M. 1975: Rb-Sr isotopic characteristics and chemistry of the 3.6 B.Y. Hebron gneiss, Labrador. Earth planet. Sci. Lett. 60, 337-338.

Black, L. P., Gale, N. H., Moorbath, S., Pankhurst, R. J. \& McGregor, V.R. 1971: Isotopic dating of very early Precambrian amphibolite facies gneisses from the Godthaab district, West Greenland. Earth planet. Sci. Lett. 12, 245259.

Bridgwater, D. \& Collerson, K. D. 1976: The major petrological and geochemical characters of the 3600 m.y. Uivak gneiss from Labrador. Contrib. Mineral. Petrol. 54, 43-59.

Bridgwater, D., Collerson, K. D., Hurst, R. W. \& Jesseau, C. W. 1975: Field characters of the early Precambrian rocks from Saglek, coast of Labrador. Geol. Surv. Can., Pap. 75-1, Part A, 287-296.

Bridgwater, D., McGregor, V. R. \& Myers, J.S. 1974: A horizontal tectonic regime in the Archaean of Greenland and its implications for early crustal thickening. Precambrian Res. 1, 179-197.

Bridgwater, D., Mengel, F., Schiøtte, L. \& Winter, J. 1990: Research on the Archaean rocks of northern Labrador progress report 1989. Current Research, Report 90-1, 227236. Newfoundland Department of Mines.

Bridgwater, D., Watson, J. \& Windley, B. F.-1973: The Archaean craton of the North Atlantic region. Phil. Trans. $R$. Soc. Lond., A273, 493-512.

Collerson, K. D. 1983: Ion microprobe zircon geochronology of the Uivak gneisses: implications for the evolution of early terrestrial crust in the North Atlantic Craton. In Ashwal, L. D. \& Card, K. D. (eds) Abstracts for the early crustal genesis field workshop, Lunar planet. Inst. tech. Rep. 83-03, 28-33.

Collerson, K. D., Kerr, A. \& Compston, W. 1981: Geochronology and evolution of late Archaean gneisses in Northern Labrador: an example of reworked sialic crust. In Glover, J. E. \& Groves, D. I. (eds) Archaean Geology. Spec. Publ. geol. Soc. Aust. 7, 205-222.

Collerson, K. D., Kerr, A., Vocke, R. D. \& Hanson, G. N. 1982: Reworking of sialic crust as represented in late $\mathrm{Ar}$ chaean-age gneisses, northern Labrador. Geology 10, 202 208.

Collerson, K. D., McCulloch, M. T. \& Nutman, A. P. 1989: Sr and Nd isotope systematics of polymetamorphic Archaean gneisses from southern West Greenland and northern Labrador. Can. J. Earth. Sci. 246, 446-466.

Compston, W., Kinny, P. D., Williams, I. S. \& Foster, J. J. 
1986: The age and $\mathrm{Pb}$ loss behaviour of zircons from the Isua supracrustal belt as determined by ion microprobe. Earth planet Sci. Lett. 80, 71-81.

Ermanovics, I. F., Korstgård, J. A. \& Bridgwater, D. 1982: Structural and lithological chronology of the Archaean Hopedale block and the adjacent Proterozoic Makkovik Subprovince, Labrador: Report 4. Geol. Surv. Canada, Pap. 82-1B, 153-165.

Finn, G. C. 1989: Rb-Sr geochronology of the Archaean Maggo gneiss from the Hopedale block, Nain Province, Labrador. Can. J. Earth Sci. 26, 2512-2522.

Friend, C. R. L., Nutman, A. P. \& McGregor, V. R. 1987: Late-Archaean tectonics in the Frringehavn-Tre Brødre area, south of Buksefjorden, southern West Greenland. $J$. geol. Soc. Lond. 144, 369-376.

Friend, C. R. L., Nutman, A. P. \& McGregor, V. R. 1988: Late Archaean terrane accretion in the Godthåb region, southern West Greenland. Nature 335, 535-538.

Garde, A. A. 1989: Retrogression and fluid movement across granulite-amphibolite facies boundary in middle Archaean Nûk gneisses, Fiskefjord, southern West Greenland. In Bridgwater, D. (ed.) Fluid movements - element transport, and the composition of the deep crust, 125-137. Dordrecht: Kluwer.

Grant, N. K., Voner, F. R., Marzano, M. S., Hickman, M. H. \& Ermanovics, I. 1983: A summary of Rb-Sr isotope studies in the Archaean Hopedale Block and the adjacent Proterozoic Makkovik Subprovince, Labrador: Report 5. Geol. Surv. Canada, Pap. 83-1B, 127-134.

Hurst, R. W. 1973: The early Archaean of coastal Labrador. In Morse, S. A. (ed.) The Nain Anorthosite Project, Labrador: Field Report 1973. Univ. Massachusetts Geol. Dep. Contrib. 13.

Hurst, R. W., Bridgwater, D., Collerson, K. D. \& Wetherill, G. W. 1975: 3600 m.y. Rb-Sr ages from very early Archaean gneisses from Saglek Bay, Labrador. Earth planet. Sci. Lett. 27, 393-403.

Kinny, P. D. 1986: 3820 Ma zircons from a tonalitic Amîtsoq gneiss in the Godthåb district of southern West Greenland. Earth planet. Sci. Lett. 79, 337-347.

Kinny, P. D., Compston, W. \& McGregor, V.R. 1988: The early Archaean crustal history of West Greenland as recorded by detrital zircons. In Ashwal, L.D. (ed.) Workshop on the growth of continental crust, Lunar planet. Inst. tech. Rep. 88-02, 79-81.

Loveridge, W. D., Ermanovics, I. F. \& Sullivan, R. W. 1987: $\mathrm{U}-\mathrm{Pb}$ ages on zircon from the Maggo gneiss, the Kanairiktok plutonic suite and the Island Harbour plutonic suite, coast of Labrador, Newfoundland. In Radiogenic Age and isotopic studies: Report 1, Geol. Surv. Can., Pap. 87-2, $59-65$.

McGregor, V. R. 1968: Field evidence of very old Precambrian rocks in the Godthåb area, West Greenland. Rapp. Grønlands geol. Unders. 15, 31-35.

McGregor, V. R. 1973: The early Precambrian gneisses of the Godthåb district, West Greenland. Phil. Trans. R. Soc. Lond., A273, 343-358.

McGregor, V. R., Friend, C. R. L. \& Nutman, A.P. 1991: The late Archaean mobile belt through Godthåbsfjord, southern West Greenland: a continent-continent collision zone? Bull. geol. Soc. Denmark, this volume.

Moorbath, S. \& Taylor, P. N. 1986: Geochronology and related isotope geochemistry of high-grade metamorphic rocks from the lower continental crust. In Dawson, J. B., Carswell, D. A., Hall, J. \& Wedepohl, K. H. (eds) The nature of the lower continental crust. Spec. Publ. geol. Soc. Lond. $24,211-220$

Morgan, W. C. 1979: Geology Nachvak Fiord - Ramah Bay, Newfoundland - Québec, 1:50,000. Geol. Surv. Can. Map $1469 \mathrm{~A}$.
Morgan, W. C. 1981: Geology Bears Gut - Saglek Fiord, Newfoundland, 1:50,000. Geol. Surv. Can. Map 1478A.

Myers, J. S. 1973: Igneous structures and textures in the Majorqap qava outcrop of the Fiskenasset anorthosite complex. Rapp. Gronlands geol. Unders. 51, 47-53.

Nutman, A. P. \& Bridgwater, D. 1984: Early Archaean tonalites and granites of the Isukasia area, southern West Greenland: development of the oldest-known sial. Contrib. Mineral. Petrol. 94, 137-148.

Nutman, A. P., Friend, C. R. L., Baadsgaard, H. \& McGregor, V. R. 1989: Evolution and assembly of Archaean gneiss terranes in the Godthåbsfjord region, southern West Greenland: structural, metamorphic, and isotopic evidence. Tectonics 8, 573-589.

Schiøtte, L. 1988: En undersøgelse af metamorfe processers betydning for tidlig-Archaeiske bjergarters geokemi og isotop-geologi i nordlige Labrador, Canada. Unpubl. lic. scient. thesis, Univ. Copenhagen.

Schiøtte, L. 1989: On the possible role of fluid transport in the distribution of $\mathrm{U}$ and $\mathrm{Pb}$ in an Archaean gneiss complex. In Bridgwater, D. (ed.) Fluid movements - element transport and the composition of the deep crust, 299-317. Dordrecht: Kluwer.

Schiøtte, L. \& Bridgwater, D. 1990: Multi stage late Archaean granulite facies metamorphism in northern Labrador, Canada. In Vielzeuf, D. \& Vidal, Ph. (eds) Granulites and crustal evolution, 157-169. Dordrecht: Kluwer.

Schiøtte, L., Bridgwater, D., Collerson, K. D., Nutman, A. P. \& Ryan, A. B. 1986: Chemical and isotopic effects of late Archaean high-grade metamorphism and granite injection on early Archaean gneisses, Saglek-Hebron, northern Labrador. In Dawson, J. B., Carswell, D. A., Hall, J. \& Wedepohl, K. H. (eds) The nature of the lower continental crust. Spec. Publ. geol. Soc. Lond. 24, 261-273.

Schiøtte, L. \& Compston, W. 1990: U-Pb age pattern for single zircons from the early Archacan Akilia association south of Ameralik fjord, southern West Greenland. Chem. Geol. $80,147-157$.

Schiøtte, L., Compston, W. \& Bridgwater, D. 1988: Late Archaean ages for the deposition of clastic sediments belonging to the Malene supracrustals, southern West Greenland: evidence from an ion probe U-Pb zircon study. Earth plan. et. Sci. Lett. 87, 45-58.

Schiøtte, L., Compston, W. \& Bridgwater, D. 1989a: Ion probe $\mathrm{U}-\mathrm{Th}-\mathrm{Pb}$ zircon dating of polymetamorphic orthogneisses from northern Labrador, Canada. Can. J. Earth Sci. 26, 1533-1556.

Schiøtte, L., Compston, W. \& Bridgwater, D. 1989b: U.Th.Pb ages of single zircons in Archaean supracrustals from Nain Province, Labrador, Canada. Can. J. Earth Sci. 26, 26362644.

Schiøtte, L., Compston, W. \& Bridgwater, D, 1989c: U-Pb single-zircon age for the Tinissaq gneiss of southern West Greenland: A controversy resolved. Chem. Geol. 79, 21-30.

Schiøtte, L., Noble, S. \& Bridgwater, D. 1990a: U-Pb mineral ages from northern Labrador: possible evidence for interlayering of early and mid Archean tectonic slices. $\mathrm{Ge}$ osci. Canada. 17, 227-231.

Schiøtte, L., Shirey, S. B., Carlson, R. W. \& Bridgwater, D. 1990b: Sm-Nd isotopic systematics of Archaean Upernavik supracrustal rocks from the Saglek to Okak area, Labrador: relation to high-grade orthogneisses of the North Atlantic craton. Extended abstract for the 3rd International Archaean Symposium, Perth, 171.

Schiøtte, L., Shirey, S. B., Carlson, R. W., Hansen, B. T., Noble, S. \& Bridgwater, D. 1990c: Sm-Nd and U-Th-Pb isotopic evidence for the southward extent of early Archaean continental crust in northern Labrador. Abstracts 
for the 7th International Congress of Geochronologists, Canberra, 90.

Stevenson, R. K. \& Patchett, P. J. 1990: Implications for the evolution of continental crust from Hf isotope systematics of Archaean detrital zircons. Geochim. Cosmochim. Acta. 54, 1683-1697.

Stockwell, C. H. 1965: Tectonic map of the Canadian shield, 1:5,000,000. Geol. Surv. Can. Map 4-1965.

Taylor, F. C. 1979: Reconnaissance geology of part of the Precambrian shield, northeastern Quebec, northern La- brador and Northwest Territories. Geol. Surv. Can. Mem. $393,99 \mathrm{pp}$.

Wardle, R. J. 1983: Nain-Churchill province cross section, Nachvak fiord, northern Labrador. Current Research, Report 83-1, 68-89. Newfoundland Department of Mines and Energy.

Weiner, R. W. 1981: Tectonic setting, rock chemistry and metamorphism of an Archaean gabbro anorthosite complex, Tessiuyakh Bay, Labrador, Canada. Can. J. Earth Sci. 18, 1409-1421. 